\title{
Practical Using Of Network Method to Logistics Chain
}

\author{
Jiři Čejka ${ }^{1, *}$ \\ ${ }^{1}$ Institute of Business and Technology in České Budějovice, Faculty of Technology, Okružní 10, \\ 37001 České Budějovice, Czech Republic
}

\begin{abstract}
The article deals with assessing the use of the CPM method (Critical Path Method) to logistics chain of the selected enterprise. The objective is to find the critical path, which is the longest possible path in the project in terms of the time required. The activities on this path are thus called critical, and necessary measures should be taken to avoid delays in these activities, as the delays would have negative impact on the whole project. This method has been developed within the Microsoft Project programme, Microsoft software that is used for creating projects, managing tasks and resources, and tracking the current situation. For the purposes of this article, the MS Project 2016 version was used.
\end{abstract}

\section{Introduction}

For a successful project creation and the consequent execution of necessary methods it is necessary to define individual activities needed to carry out the entire process. Activities can be divided into individual levels whereby the better orientation in the project can be achieved. Durations of the activities are then defined, i.e. when the task starts and finishes, dates will be automatically generated [1-5].

An important point is to define continuity of individual tasks (definition of preceding and following tasks, i.e. which activities must be initiated after the completion of the others and which activities can be carried out at same time) and creation of interrelationships. This procedure provides a clear structure upon which the further analyses, such as the network analysis and the critical path resulting from it, can be made.

The project processing along with the determination of interrelationships and following tasks can be characterized as follows:

1. Purchase order from a customer -1 day

2. Purchase order processing -3 days

3. Logio

3.1. Production planning -2 days

3.2. Raw material planning -2 days

3.3. Distribution planning -2 days

3.4. Capacity planning -2 days

4. Collection of milk - 1 day

\footnotetext{
*Corresponding author: cejka@mail.vstecb.cz
} 
5. Provision of packaging

5.1. Enough packaging in stock -1 day

5.2. Lack of packaging in stock - 30 day

6. Production -6 days

7. Treatment -20 days

8. Packing

8.1. Packing without delay -1 day

8.2. Packing with a delay -1 day

9. Storage

9.1. Storage without delay -1 day

9.2. Storage with a delay -1 day

10. Distribution

10.1. Distribution without delay -1 day

10.2. Distribution with a delay -1 day

The main project levels are identical with the main activities in the process - obtaining a purchase order from a customer, purchase order processing, logistic plans in the Logio system, milk collection, provision of necessary materials, production, treatment, packing, storage and distribution. Figure No. 2 shows that a portion of activities contains other partial tasks which need to be done and which represent the process behaviour in certain situations.

Duration in days was defined for all activities and the preceding and following activities were determined. As a result, individual activities amalgamated and the continuity of the entire process was created [4-7].

\section{Solutions in graphical representation}

The programme allows a graphical representation by means of the Gantt chart, which is a tool showing the sequence and time data. It allows us to carry out simple planning and checks of the partial activities as well as bigger units. This chart ranks among the bar charts, i.e. it represents individual activities on the time line using the bars. Thanks to this representation, the phase and dependency of activities can be easily found out.

The Gantt chart created upon the analysed process can be seen in the right section in Figure No. 3. Each process activity has a corresponding graphical representation on the line. The size of bars in the chart depends on the duration of individual activities and the activities are connected with the links which correspond to their sequence and interrelationship [8-10]. 


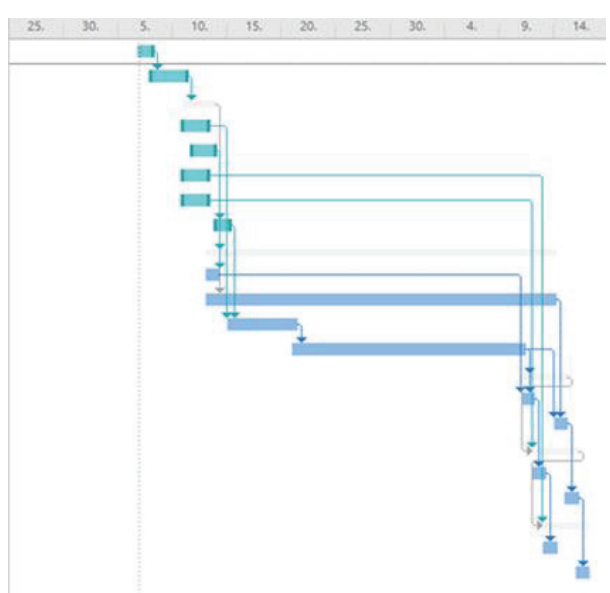

Fig. 1. Gantt chart in MS Project. Source: author

For better overview and time orientation, the flow chart No. 1 is available. This flow chart was generated based on the theoretical basis in Chapter 2 and the processed information.

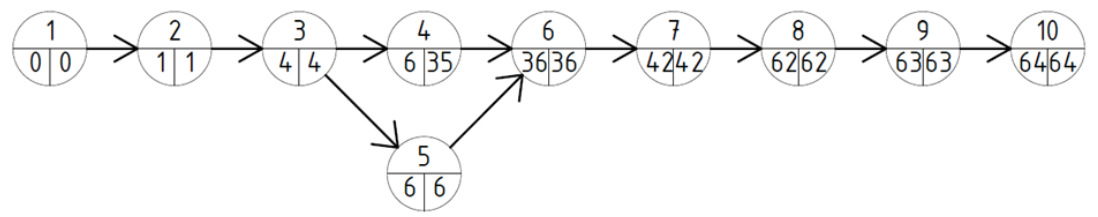

Fig. 2. Flow chart. Source: author

Here, you can see the sequence and interrelationships of individual activities, or more precisely, preceding activities of individual tasks. You can also see the duration of individual activities (numbered edges) and the earliest possible starts (left No. in the node) and ends of individual activities (right No. in the node) [8-11].

\section{Critical path}

Using the programme and the flow chart tool we can display the critical path upon the Gannt chart. The critical path is defined as the longest possible path in the project in terms of the time required. It is a suitable tool for estimation of the project duration. It leads from the initial (first activity) to the end point (last activity) of the chart, i.e. every project has at least one critical path. Activities lying on this path require more time to do; they do not have any time reserve and need to be focused on if the projects should be completed in time. Their delay would have an adverse effect on the entire project. The critical path is reflected in the time planning and project management of nearly all phases of its life cycle. The critical path of this project is shown in the Graph No. 2. The activities which form this critical path include:
1) Purchase order from a customer
2) Purchase order processing
3) Logio - raw material planning
4) Milk collection
5) Lack of packaging in stock
6) Treatment 
7) Packing with a delay

8) Storage with a delay

9) Distribution with a delay

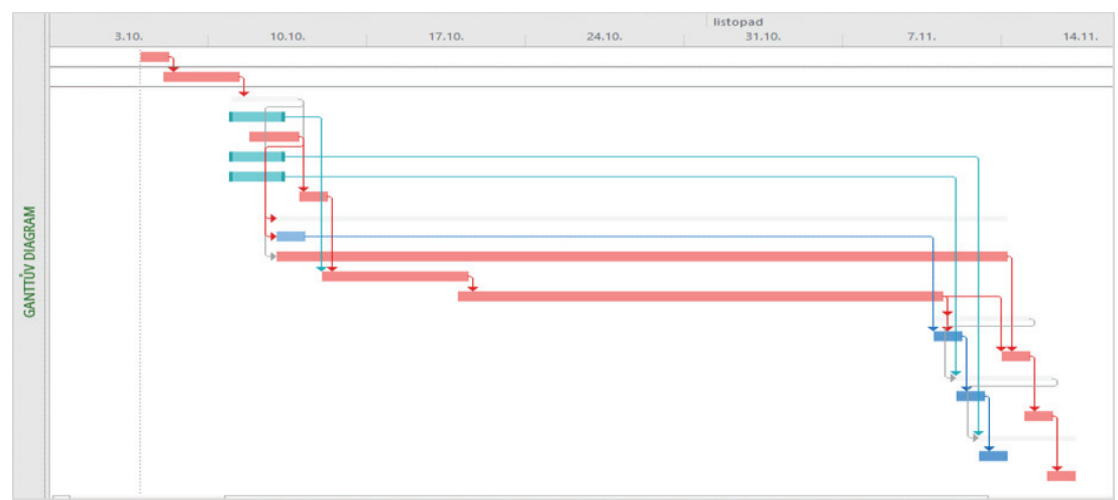

Fig. 3. Critical path of the process in MS Project. Source: author

The critical path always begins with the first activity. The second activity is included in the critical path because no other activities are carried out simultaneously and, hence, the critical path must go through them. The next item is processing in the Logio system which includes the raw material planning as a critical activity, followed by the collection of milk again included due to a single activity being carried out at a given time. The chart begins to branch out with the next activity - the critical path goes through the lack of packaging in stock [10-13].

The packaging storage room is located in the production plant complex in Český Krumlov. If the packaging is in stock, it can be transported to the production plant during one day and the packing operation can start without any time delays. In case of the lack of packaging, it must be ordered, which is done at the purchase order processing phase, i.e. we can ensure the delivery during the production process which lasts 26 days. Manufacture and delivery of packaging from the supplier which has its central warehouses in Prague takes 30 days.

The Gantt chart helped us to establish that the delay in packing of the products is, based on these assumptions, 3 days when the products are in stock and wait for the packing process. This restraint will cause a delay in the follow-up activities, namely the distribution to the central warehouse in Jesenice and on to the customers. The company has a certain amount of stocks, i.e. an emergency reserve; these, however, are based on the expert estimation of the quantity consumed in previous years. In case of unexpected demand or delay on the supplier's part, the company may run out of stocks [8-11].

The next activity is the treatment, i.e. an activity when the produced cheese ripens in the ripening cellars. This activity can be neither limited nor eliminated.

Packing with a delay happens at the time when the packaging material is not in stock and the production of the Jihočeská niva cheese is done. Packaging must be ordered - as we know, it is already ordered at the purchase order processing phase. The above figure shows that the delivery of packaging in this situation happens on 14 November, while the treatment ends on 11 November. This implies that the products have to wait in the factory for 3 days until they are packed in the necessary packaging, foil and cardboard boxes. With every other day of delay, the products lose their value. This also results in the delayed entry of the products into the central storage in Jesenice and the next distribution to the customers. The critical path ends with the distribution of the cheese to customers [12-14]. 


\section{Conclusions}

The article is concerned with the CPM method, i.e. a critical path method, which is applied on the production process of the selected dairy product of the Madeta company - the Jihočeská niva cheese.

The paper is divided into two parts - the first one focuses on the theoretical determination of the given issue. During this phase I obtained the knowledge which I could apply later. This part also deals with the construction of the flow chart needed later.

The second part focuses on the application of the network analysis method, especially the application of the CPM method on the logistic chain of the selected company. The Microsoft programme, Microsoft Project 2016, was used to solve the problem. Using this programme, the project consisting of individual activities in the chain was created, including determining of the following activities, the entire sequence and durations of individual tasks.

This paper is supported by the research project "From horse-drawn railway to intermodal transport" within Visegrad Fund.

\section{References}

1. V. Cempírek, K. Pivoňka, J. Široký, Fundamentals of Transportation Technology and Management, 3rd reworked issue, 120 p. (University of Pardubice, Czech Republic, 2002)

2. K. Hrazdilová Bočková, Project Management: Textbook (M. Koláček, 2016)

3. J. Jablonský, M. Maňas, P. Fiala, Multi-criteria Decision-Making, 1st issue, 316 p. (Prague: University of Economics in Prague, Czech Republic, 1994)

4. J. Kubát, Lagerstandortoptimierung mit Hilfe des Verfahrens Branch und Bound, (Ekonomicko matematický obzor 11, 65-83, Czech Republic, 1975)

5. P. Matejko, L. Černá, J. Majerčák, International Scientific Conference - Diagnostics Business and Controlling Logistics Slovak Republic (University of Žilina, Slovak Republic, 2012)

6. O. Pasch, Microsoft Share Point, Practical Guide of a User (Brno: Computer Press a.s., Czech Republic, 2011)

7. O. Stopka, M. Chovancová, J. Ližbetin, V. Klapita, Nase More 63, 3, 195-199 (2016), DOI: $10.17818 / \mathrm{NM} / 2016 / \mathrm{SI} 22$

8. L. Unčovský, et al., Operational Analysis in Company Management (Alfa, Bratislava, Slovak Republic, 1985)

9. V. Zitrický, J. Gašparík, L. Pečený, Transport Problems 10, 59-72 (2015)

10. P. Fiala, Production System Modelling and Analysis, 1st issue, 260 p. (Prague: Professional Publishing, Czech Republic, 2002)

11. I. Kubasakova, B. Poliakova, L. Krzywonos, Logi - Scientific Journal on Transport and Logistics 4, 2, 39-46 (2013)

12. J. Jablonský and M. Dlouhý, Efficiency Evaluation Models of Production Units, 1 st issue, 184 p. (Prague: Professional Publishing, Czech Republic, 2004)

13. R. Hindls et al., Statistics for Economists, 7th issue, 420 p. (Prague: Professional Publishing, Czech Republic, 2006)

14. J. Janáček, Doprava 35, 4, 172-175 (1993) 